Department of Clinical Studies, College of Veterinary Medicine

King Faisal University, P.O. Box 55011, Al-Hasa 31982

\title{
Screening of Domestic Ruminants Sera for the Presence of Anti- camel pox Virus Neutralizing Antibodies at Al-Hassa District of Saudi Arabia
}

(With 2 Tables and 1 Figure)

By

Fadhel M.T. Housawi

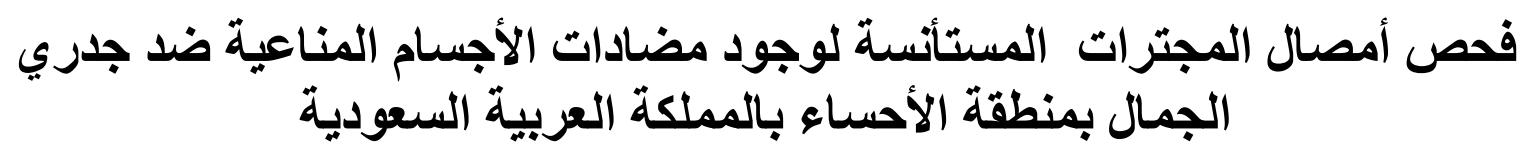

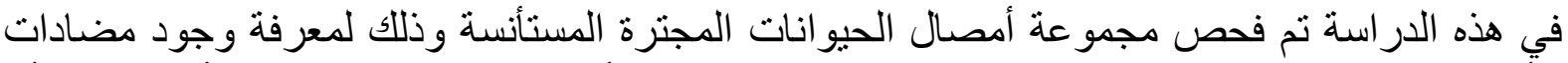

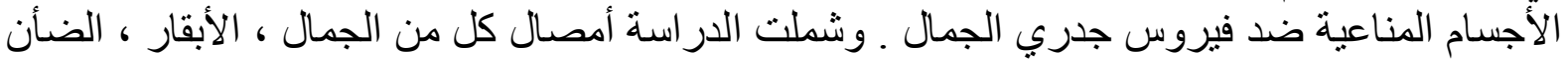

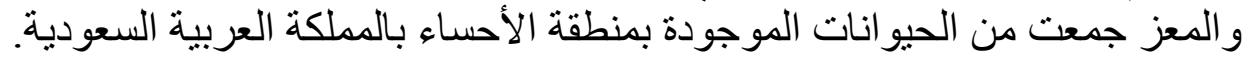



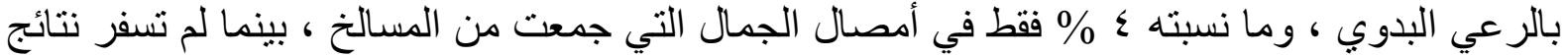

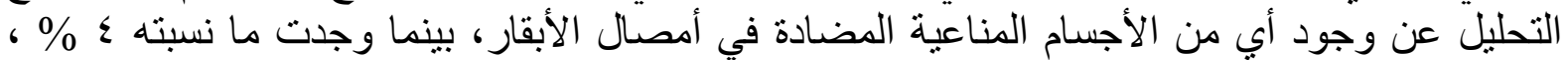

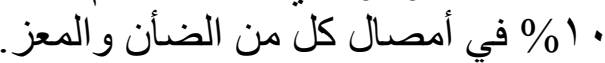


جدري الجمال في المملكة العربية السعودية.

\section{SUMMARY}

Examination of ruminants sera for the presence of anti-camel pox virus neutralizing antibodies in Al-Hassa district has revealed that, the prevalence in the nomadic pastorates camels was $21 \%$, while in abattoir camels' sera $4 \%$. Bovine, ovine and caprine sera have produced zero, 6 and 10\% prevalence. The presence of such neutralizing antibodies in the animal sera was discussed in relation to the epidemiology of the disease in the country.

Key Words: (Camelus dromedarius), anti-camel pox virus antibodies, Al-Hassa, KSA. 


\section{INTRODUCTION}

Camel pox is an infectious disease of camels, manifested by cutaneous nodules on the skin (Rash lesions) that cover the mouth, head, neck, legs and perineal area, or generalized lesions that cover all the body of both Camelus dromedarius or Camelus bactrianus camels. The disease was reported from all camel raising areas, except Australia (Wernery and Kaaden, 1994).

The causative virus belongs to the genus orthopoxvirus. Camel pox virus isolates from Africa, the Middle East and Russian were found to be characteristically similar (Davies et $\underline{\text { al., }}$ 1985).

Since the first isolation and identification of the camel pox (CP) in Saudi Arabia (Hafez et al., 1986), several forms of the disease were noted. These included a mild form, slow spreading form and also a severe devastating form

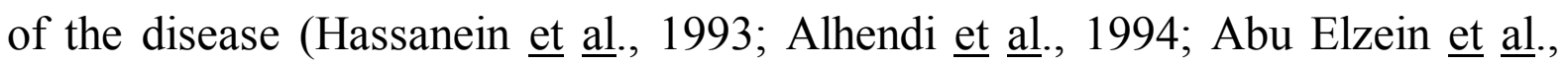
1999; Hussein and Al-Mufarrej, 1999). The disease has also been reported in some of the neighboring countries such as Iran (Baxby, 1972), Iraq (Al-Falluji et al., 1979), Yemen (Odend'Hal, 1983), United Arab Emirates (Kaaden et al., 1992) and Bahrain (Higgins et al., 1992).

Thorough investigations regarding the prevalence and in-depth epidemiological studies of the disease are yet to be accomplished.

The present work examines the possible presence of anti-camel pox neutralizing antibodies, in other domestic ruminants. 


\section{MATERIALS AND METHODS}

\section{Serum Samples:}

A total of 350 serum samples were collected from domestic ruminants. Two hundred were from camels, 50 were from cattle and 100 from sheep and goats. The samples were then stored at $-20^{\circ} \mathrm{C}$.

\section{The Reference camel pox virus:}

A reference tissue culture adapted camel pox virus (Jouf strain), previously isolated and identified (Hafez et al., 1992) was kindly provided by Dr. Habib Al-Khalf, vaccine research centre. The virus was twicely propagated on vero cells and titrated before its use in the serum neutralization test (SNT).

\section{The Microserum Neutralization Test (SNT):}

The micro SNT, was used as described by Davies et al., (1985), with the modification that, the test sera were diluted in (MEM) medium, without serum. Series of duplicate two fold dilution were made for each tested serum starting from $1 / 10$. The diluted serum was added to an equal volume of predetermined camel pox virus, containing $100 \mathrm{TCID} / 50$ to each well. The mixture was incubated at $37^{\circ} \mathrm{C}$ for $1 \mathrm{~h}$ and then overnight at $4^{\circ} \mathrm{C}$. A $0.05 \mathrm{ml}$ of suspended vero cell culture was added to each well at concentration of $10^{6} / \mathrm{ml}$, prepared in $2 \%$ fetal calf serum (FCS) maintenance medium. The plates were incubated at $37^{\circ} \mathrm{C}$ for 3-5 days. 


\section{RESULTS AND DISCUSSION}

Results of the SNT (Tables $1 \&$ 2) revealed presence of neutralizing anti camel pox antibodies in ruminants at Al-Hassa district (Fig 1). Of the total serum samples studied, 33 were found positive $(9.14 \%)$. When the serum samples were grouped according to their species and type of management, it was found that the prevalence in nomadic camels was $21 \%$, and in abbatoir camels it was $4 \%$ camels. It must be mentioned that camel pox vaccination is not practiced, so far, by the official authority of the Ministry of Agriculture in this region (Dr. Yousuf, personal communication). This shows that the seroconversion in these camels was due to previous exposure to camelpox virus.

Sheep and goats produced $6 \%$ and $10 \%$ prevalence respectively, and the prevalence in cattle was $0 \%$ (Table 2 ). In this country, Sheep \& goats are usually reared in close contact with camels, so their exposure to the camelpox virus cannot be ruled out.

Earlier studies by Davies and Otema, (1981) did not reveal crossrelationship between strains of capripox virus and camel pox viruses. However, anti-camel pox neutralization antibodies were detected in the sheep and goats serum of the present study.

Cattle produced $0 \%$ prevalence. That could probably be due to fact that cattle are raised in closed farms and this is the typical management system of raising cattle in Saudi Arabia. They usually don't come in contact with any other animal species. 
Because, there is only little information is available about the epidemiology of camel pox in Saudi Arabia, a nation-wide study is required to investigate the exact prevalence of the disease among camels and to verify the response of other ruminants which share grazing areas with camels.

Table 1: End - point titres of neutralizing antibodies of ruminants' sera against camel pox virus.

\begin{tabular}{|l|rrrrrrrrr|}
\hline $\begin{array}{l}\text { Source of the } \\
\text { Sample serum }\end{array}$ & \multicolumn{10}{|c|}{ Reciprocal end-point titres } \\
\hline $\begin{array}{l}\text { Nomadic } \\
\text { Camel serum }\end{array}$ & 0 & 10 & 6 & 8 & 40 & 80 & 160 & 320 & 640 \\
\hline $\begin{array}{l}\text { Abattoir } \\
\text { Camel serum }\end{array}$ & 0 & 1 & 3 & 0 & 0 & 0 & 0 & 0 & 0 \\
\hline $\begin{array}{l}\text { Cattle } \\
\text { Serum }\end{array}$ & 0 & 0 & 0 & 0 & 0 & 0 & 0 & 0 & 0 \\
\hline $\begin{array}{l}\text { Sheep serum } \\
\text { Nomadic) }\end{array}$ & 0 & 1 & 2 & 0 & 0 & 0 & 0 & 0 & 0 \\
\hline $\begin{array}{l}\text { Goat serum } \\
\text { (Nomadic) }\end{array}$ & 0 & 3 & 1 & 1 & 0 & 0 & 0 & 0 & 0 \\
\hline
\end{tabular}

The end-point titer was taken when 50 percent or more of the cytopathic effects of the camel pox virus was suppressed, as the reciprocal of the dilution (Davies et al., 1985). 
Table 2: Number of positive serum samples tested against camelpox Virus.

\begin{tabular}{|l|c|c|c|}
\hline $\begin{array}{l}\text { Type of the } \\
\text { animal sample }\end{array}$ & $\begin{array}{c}\text { No. of tested } \\
\text { Sera }\end{array}$ & $\begin{array}{c}\text { No. of } \\
\text { Positives }\end{array}$ & $\begin{array}{c}\% \\
\text { positive }\end{array}$ \\
\hline $\begin{array}{l}\text { Nomadic } \\
\text { Camel serum }\end{array}$ & 100 & 21 & $21 \%$ \\
\hline $\begin{array}{l}\text { Abattoir } \\
\text { Camel serum }\end{array}$ & 100 & 4 & $4 \%$ \\
\hline Cattle & 50 & 0 & $0 \%$ \\
\hline Sheep serum & 50 & 3 & $6 \%$ \\
\hline Goat serum & 50 & 5 & $10 \%$ \\
\hline Total & 350 & 33 & $32 \%$ \\
\hline
\end{tabular}

\section{Acknowledgement:}

The author would like to thank Prof. ELTayb Abu ELZein for valuable comments, and Mr. A. Khars for technical assistance. 


\section{REFERENCES}

Abu Elzein, E.M.E.; Gameel, A.A.; Ramadan, R.O.; and Housawi, F.M.T. (1999). An eruptive moderate form of camelpox infection in deromedary camels (camelus dromedarius) in Saudi Arabia. Rev. Sci. Tech. Off. Int. Epiz., 18, 749-752.

Al-Falluji, M.M.; Tantawi, H.H. and Shony, M.O. 1979. Isolation, identification and characterization of camel pox virus in Iraq. J. Hyg. Camb. 83, 267-273.

Al-Hindi, A.B.; Abu Elzein, E.M.E.; Gameel, A.A. and Hassanein, M.M. (1994). A slow-spreading Mild form of camelpox infection. J. Vet. Med. 'B' 41, 71-73.

Baxby, D. (1972). Small pox-like viruses from camels in Iran. Lancet. II: 1063-1065.

Davies, F.G. and Otema, C. (1981). Relationships of capripox viruses found in Kenya with two Middle Eastern strains and some orthopox viruses, Research in Vet. Sci. 31, 253-255.

Davies, F.G.; Mbugua, H.; Otema, C. and Wilson, A. (1985). The prevalence of antibody to camel pox virus in six different herds in Kenya. J. Comp. Patho. 95, 633-635.

Hafez, A.M.; Al-Sukayran, A.; dela Cruz, D.; Mazloum, K.S.; Al-Bokmy, A.M. and Amjad, A.M. (1992). Development of a live cell culture camelpox vaccine. Vaccine, 10, 533-539. 
Hassanein, M.M.; Abu Elzein, E.M.E.; Al-Afaleq, A.A.; Al-Hindi, A.B. and Amin, M.M. (1993). A survey for camel pox in the Eastern region of Saudi Arabia. J. Egypt Vet. Med. Asson. 53, 461-465.

Higgins, A.J.; Silvey, R.E.; Abdelghafir, A.E. and Kitching, R.P. (1992). The epidemiology and control of an outbreak of camel pox in Bahrain. Proc. $1^{\text {st }}$ Int'1. Camel Conf. and Africa. J. Med. Entomol. 15, 307-417.

Hussein, M.F. and Al-Mufarrej, S.I. (1999). Some clinico pathological aspects of camelpox in Saudi Arabia. J. King Saudi Univ. Agric. Sci. 2, 113-120. Kaaden, O.R.; Klopries, K.; Wernery, U. and Drommer, W. (1992). Establishment and characterization of a camel skin cell line. In: Proc. $1^{\text {st }}$ Int'l. Camel Conf., 402.

Odend'Hal, S. (1983). The geographical distribution of animal viral diseases. Academic Press, New York, 99.

Wernery, U. and Kaaden, O.R. (1994). In the infectious diseases of camelids. Blackwell Wissenschaft, Berlin, 81-85. 


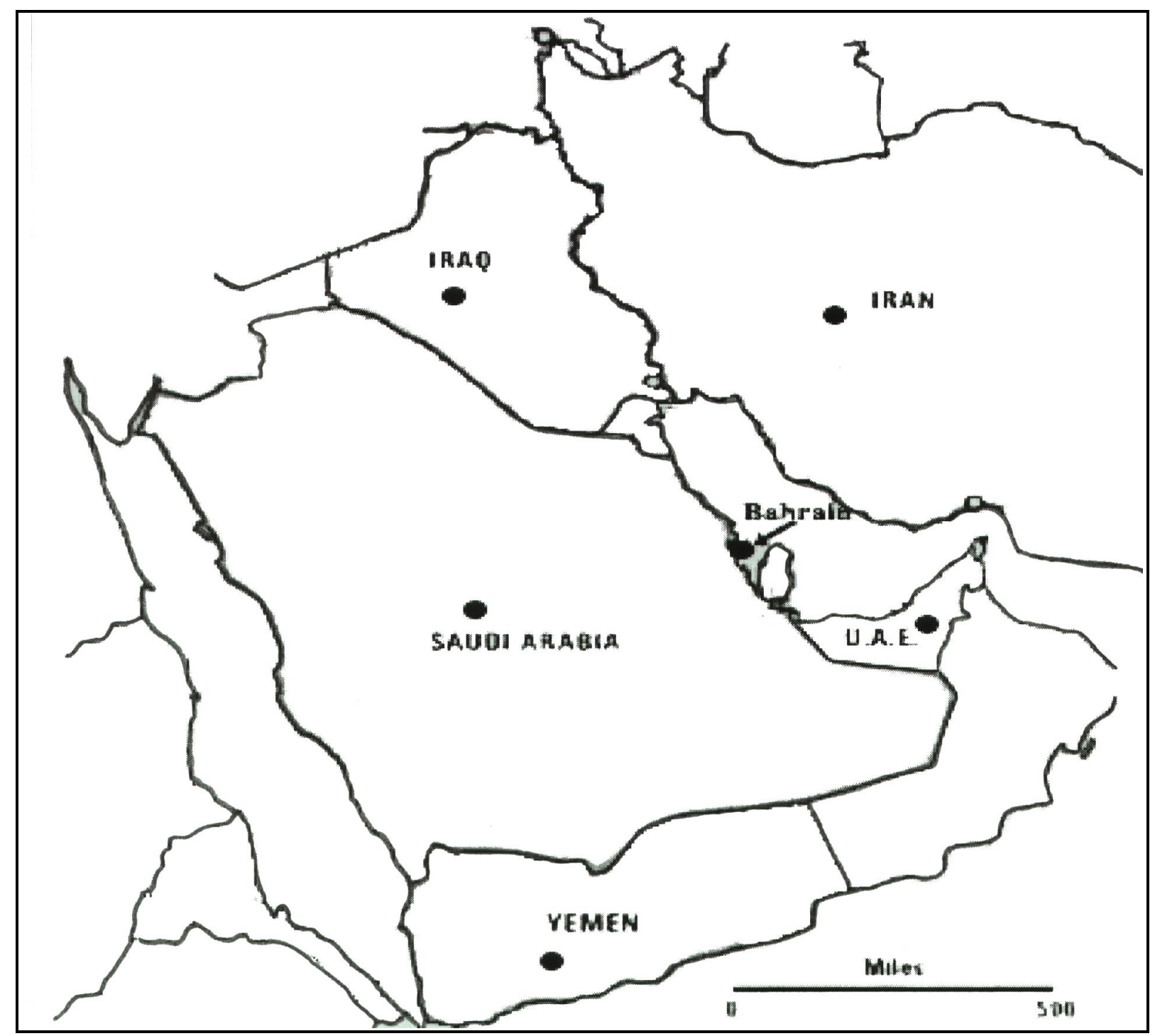

Fig. (1): Location where camel pox were reported in and around the Arabian Peninsula. 